\title{
The Theme of Escape in Celeste Ng's Everything I Never Told You
}

\author{
LAI Yuli \\ College of Foreign Studies, Jinan University, China
}

Received: August 26, 2021

Accepted: August 31, 2021

Published: January 31, 2022

To cite this article: LAI Yuli. (2021). The Theme of Escape in Celeste Ng's Everything I Never Told You. Asia-Pacific Journal of Humanities and Social Sciences, 1(4), 035-039, DOI: 10.53789/j. 1653-0465. 2021.0104. 005

To link to this article: https://doi. org/10.53789/j. 1653-0465.2021.0104.005

Abstract: Celeste Ng's debut novel Everything I Never Told You describes the depressive situation of an interracial family in America. Surrounding a sixteen-year-old girl Lydia's death, the novel portrays the family's secrets and suffering on racial and gender issues. As every family member in the novel attempts to run away, this thesis aims to clear the theme of escape in the novel. Through analyzing the essence of their escape and exploring the hidden reasons for the escape, the paper reveals the fatal blow of racial discrimination and gender prejudice on ethnic and gender minorities in America.

Keywords: escape; racial discrimination; gender prejudice; Everything I Never Told You

Notes on the contributor: LAI Yuli holds a master's degree in Bachelor of Art. She is from College of Foreign Studies, Jinan University with academic interests in English and American literature. Her email address is 1261495056@ qq. com.

\author{
無處可逃處處逃 \\ —《無聲告白》的逃離主題解讀 \\ 賴玉麗 \\ 暨南大學
}

\begin{abstract}
摘 要: 華裔作家伍綺詩的處女作《無聲告白》描述了一個華裔男子和美國白人結合的跨種族家庭的困境, 詹姆斯 家中所有成員掙扎著逃離。本文從後殖民主義和女性主義的視角出發, 聚焦於詹姆斯家庭的逃離事件, 通過分析 他們逃離的本質及探索根源, 揭示了種族歧視和性別偏見才是壓垮少數族裔家庭的致命因素。
\end{abstract}

關鍵詞: 逃離; 種族歧視; 性別偏見; 《無聲告白》 


\section{引言}

伍綺詩的《無聲告白》圍繞莉迪亞的死亡展開敘述,在追溯其死因中揭開了家庭秘密和背後受到的壓 迫。正如《新時代》雜誌所報導, 該小說描述了社會群體中異類的負擔和壓力 ${ }^{\mathbb{1}}$ 。《無聲告白》揭露了美國華 裔和女性在美國社會中的地位和遭遇, 小說中的邊緣人物不斷掙扎, 企圖打破種族的界限和性別的偏見。細 讀小說後,本文進一步探索小說中的逃離主題。

\section{一、詹姆斯的“白色面具” : 族裔身份的逃離}

正如蒲若茜所言, 華裔後代們在家庭和族群的壓力之下, 常常產生逃離唐人街的衝動 ${ }^{2}$ 。儘管《無聲告 白》不再禁銅於唐人街,但是詹姆斯一家作為華裔後代, 同樣經歷了絕望的逃離過程。實際上,他們的逃離 是對痛苦的生活尋找解脫的渴望。小說主人公們不斷抗爭, 嘗試用各種方式去捋脫現實中的焦慮和恐懼以 及種族、性別帶來的刻板印象。

詹姆斯通過身份扮演,戴上 “白色面具” 以期隱藏自己的華裔身份。而這無奈的身份扮演策略,正是邊 緣群體在不公平的政治文化和惡劣的生存環境之下賴以存活的工具 ${ }^{3}$ 。一方面,詹姆斯拒絕提及自己的家 族歷史, 作為華裔, 他對中國歷史所知甚微, 卻熱衷於研究 “美國最經典的文化課題” (4。強烈的對比反映了 詹姆斯隱藏自己華裔身份的決心。榮格的人格面具理論指出, 人們通過人格面具去表現自己,迎合他人, 從 而隱藏真正的性格 ${ }^{(5)}$ 。詹姆斯戴上人格面具表現出來的對歷史的忘卻和對主流身份的追逐不休, 實為對族 裔身份的逃避。另一方面,詹姆斯將打破種族界限的希望寄託在與瑪麗琳的婚姻上。這場跨種族聯姻是詹 姆斯逃離身份焦慮的進一步嘗試。在詹姆斯的心裏, 瑪麗琳是主流社會的代表, 她 “能夠完美地融人人 群” @。與瑪麗琳結合, 就意味著被主流社會所容納。這種諷刺的錯位想像, 反映了詹姆斯對於掙脫美國社 會異化目光的渴望。可以說, 這椿婚姻是詹姆斯融人主流的策略, 更是他自己定義的對於美國華裔身份的逃 離。

那麼, 是什麼導致詹姆斯如此渴望逃離呢? 即使作為大學教授,詹姆斯依然無法擺脫種族歧視的困擾。 他對於自己族裔身份的逃離, 是一種自我殖民的體現。霍爾曾指出, 白人社會通過異類眼光來使華裔成為他 者。就是這種物化的凝視, 使得華裔自我產生壓力進而自我否定 ${ }^{(7)}$ 。詹姆斯的一生都被白人 “凝視”。就在 詹姆斯上學的第一天,他的黑眼睛被同桌質問“你的眼睛怎麼了? ” ${ }^{8}$ 在這種凝視之下,詹姆斯明晰其異於白 人並為此而羞恥。這種灼熱的凝視在潛移默化中使詹姆斯用美國主流社會的價值觀進行自我反省, 從而加 深了其對族裔身份的厭惡。他甚至把自己看成是 “冒名頂替的騙子” (9)。正如薩特所言, 他者的凝視是自我 建構的重要組成部分 ${ }^{10}$ 。詹姆斯眼中的自我, 其實就是白人對華裔的刻板印象。他無法客觀看待自我, 而是 扮演著西方 “觀察者”, “審判” (1)。一個來自東方的邊緣人物, 用白人主流觀, 將華裔身份的自我排擠為美國 社會的“局外人”。這種強烈的他者歧視,使詹姆斯愈發憎恨自己的美國華裔身份。

詹姆斯的自我輕視背景可以追溯到 1882 年《排華法案》。排華法案禁止華人移民居留長達六十年之 久, 中國人只能假借已紮根華人的親屬之名苟活在美國。因此, 美國出現了大批 “紙兒子”。頂著假名的華 裔只能謹慎卑微地生存, 以防被驅逐出境。作為 “紙兒子” 的兒子, 詹姆斯從小生活在惶恐中, 歷史的創傷使 他 “把敬畏白人變成習慣” (12。即使白人員警對女兒的死表現冷漠, 他依然克制自我對員警保持禮貌。此外, 法農在《黑皮虞, 白麵具》中曾提及,殖民國通過霸權控制所屬國的政治和精神,使黑人在壓迫下產生自卑情 結和劣等民族的痛苦 ${ }^{13}$ 。在種族歧視的排擠下, 美國華裔同樣經歷 “自卑情結”。詹姆斯就因為未被美國主 
流社會接納而深受自我否定的痛苦。可見詹姆斯對於美國華裔身份的回避, 潛移默化的自我殖民, 其實是在 逃離美國主流對華裔的偏見和歧視。

\section{二、瑪麗琳離家出走: 性別身份的逃離}

儘管瑪麗琳是美國人, 作為女性, 她還是逃脫不了被邊緣化的結局。女權主義人類學家蓋爾 - 魯賓 (Gayle Rubin)聲稱, 不同的社會根據生物學差異來定義各種角色並賦予他們相應的文化期望 ${ }^{\circledR}$ 。女性因其 特有的生育機能被定義為母親, 男權社會則直接以 “母親” 的名義要求女性為家庭犧牲一切。女性遭受著社 會的不公平對待, 因此對自己的性別角色感到焦慮不安。瑪麗琳就是一個典型的例子。可貴的是, 瑪麗琳不 斷與傳統的女性刻板印象做抗爭,拒絕被定義為“家庭主婦”。《無聲告白》發生在 20 世紀 50 至 70 年代,彼 時女權運動在美國盛行。瑪麗琳的逃離正是受到女權運動的啟蒙和對女性社會地位受壓迫的反抗。第一次 女性主義浪潮之後,女性意識逐漸覺醒。瑪麗琳受波伏娃 “女人並不是天生的,而是成為女人的”這一論斷 的啟發, 意識到女性擁有自己的價值。因此, 瑪麗琳決定撥正性別偏見, 為女性自我的價值而鬥爭。正如瑪 麗 - 戴利所倡議, 破除刻板印象應該將内化了男性優越性的偶像從滋生了男性優越感的意識形態和文化體 制中驅除出去 ${ }^{10}$ 。瑪麗琳對於打破偏見的第一步是選擇傳統意義上 “適合男生的” 物理研究。在女性主義思 想的激勵下, 她還通過努力成為最優秀的學生, 用實力衝擊著充滿男性優越感的社會群體。她對 “家庭主 婦” 角色的抗拒反映了她對於逃離家庭束縛, 追求女性獨立的渴望。成為醫生是瑪麗琳顛覆男權社會對於 女性的刻板印象的夢想依託。

然而, 瑪麗琳為醫生夢想抛家棄子的選擇只是她打破性別偏見的抗爭,而非真正的熱愛。莉迪亞的質問 一語道破這點: 她們成為傑出的科學家到底是 “因為她們的興趣還是不得以而為之? ” 這也從側面反映了社 會對女性的不公逼迫女性不得不放棄家庭和興趣。更為嚴重的是, 瑪麗琳把自己的女權鬥爭投射到女兒身 上。瑪麗琳之所以愈發激進, 是因為儘管第二次女權運動浪潮試圖為女性尋求各方面平等, 由於内化的傳統 性別觀, 女性仍處於男權的壓迫之下。在美國人傳統的觀念裏, 婦女應該留在家中照顧孩子和做家務, 其他 抱負則是男人的責任 ${ }^{18}$ 。這種男性主導的角色分工將女性的活動範圍局限於家中, 使其成為 “家庭的天使” 一這種偽善的讚譽已經內設了女性低於男性的不平等地位。對於瑪麗琳對研究員的申請, 湯姆嘲諷道“我並 不認為你是認真要工作的, 畢竟你還有孩子和丈夫要照顧” ${ }^{10}$ 。湯姆的戲謔代表了當時大多數男性的態度: 女人應該待在家中伺候丈夫和孩子, 可見當時女性地位之低。更可怕的是, 瑪麗琳的媽媽, 一個被父權制壓 迫的受害者, 也要求瑪麗琳做個 “好妻子”。從受害者變身男權社會的代言人, 這個迴圈的悲劇展現了男權 思想對社會的侵蝕之深。在根深蒂固的偏見之下, 瑪麗琳只能極力反抗, 變成激進的女權主義者。

\section{三、“夾縫”之殤: 混血後代的困境與逃離}

作為跨種族家庭的孩子, 内斯和莉迪亞在兩種文化的衝撃之下備受煎謷,遭受著種族歧視的雙重傷害。 首先, 內斯和莉迪亞因為美國華裔後代的身份而被白人群體排斥。儘管其言行無二於美國人, 他們仍被嘲笑 為“中國佬” ${ }^{20}$ 。内斯喜歡安靜思考,那些白人同學就嘲弄他 “過於矮小和笨拙”而無法加人他們的體育隊。 賽義德在《東方主義》中指出, 西方將東西方的不同描述成為東方的弱點和落後, 進而在政治上採取侵蝕的 策略 ${ }^{2}$ 。美國白人對於內斯的評價和東方主義策略如出一較: 他們將華裔的性格特點粗暴地歸納為中國人 的低劣品質, 以此顯露自我種族的優越性。莉迪亞則被同學孤立為只會學習的 “中國娃娃”。在同樣壓抑的 環境之下, 華裔後代無法擺脫父輩遭受過的種族歧視。因此, 内斯和莉迪亞也愈發内向而對公眾場合產生疏 
離感。這種內在鄉往與疏離的矛盾使得他們自我憎恨,更加厭惡自己的華裔身份。

內斯和莉迪亞不僅遭受主流社會的排擠, 在跨種族的家庭裏也無法獲得平靜。內斯的父母鮮少關注其 成長,父親詹姆斯更是時常對他發脾氣。實際上, , 斯是詹姆斯的“種族影子”。人們常將自己不受歡迎的 亞裔特徵投射到種族影子之上, 然後不斷對其進行否定和疏遠 ${ }^{2}$ 。當詹姆斯發現內斯在泳池邊躊躇時, 他的 希望破滅了。眼前膽怯的內斯如同當年的自己, 被差辱的歷史湧上心頭,使他想要逃避。因此,詹姆斯刻意 疏離內斯。在雙重淡漠的環境中, 內斯將他的目光投向天空。黃秀玲曾提出, “飛行可能是挑戰的行為, 也 可以意味著逃離” ${ }^{3}$ 。天空是自由和遠離實際的象徵。内斯對天空的執著響往反映了他對現實的排斥和對 自由的渴望。莉迪亞反而承受著父母過度的期待。“種族差異最直接體現於生理特徵之上, 支配國通過強 調不同的生理特性來彰顯他們的優越感” ${ }^{24}$ 。擁有白皮膚藍眼睛的莉迪亞成了父母的精神寄託。詹姆斯對 莉迪亞融人主流社會的願望和瑪麗琳出類拔萃的期待發生了衝突,也使莉迪亞陷人兩難困境。特別是詹姆 斯, 當他意識到自己無法被美國主流社會接納時,他把所有希望寄託在莉迪亞的身上。他將自己不受歡迎的 原因歸各於外表和交流技巧的缺乏, 給莉迪亞買交友指導書籍和漂亮的衣裙。殊不知,真正讓他們受到排擠 的不是沒有白皮膚，而是他們無法改變的華裔身份。莉迪亞明白在種族偏見之下她無法達到父親的期望,那 些禮物更像是父親給她套上的枷鎖。然而, 為了取悅父母,莉迪亞還是接受了他們的安排。所有的痛苦埋在 莉迪亞的心裏, 當唯一理解她的內斯去上大學之後, 莉迪亞感到自己被抛棄了。消極的情緒使她產生強烈的 逃離感,企圖尋求自我保護融。當莉迪亞再也無法忍受父母的牽制時,她決心要和這種高壓生活切斷聯繫。 她將庇護所的選擇投向了離家不遠處的湖。那個湖是唯一能夠讓莉迪亞感到輕鬆而 “無拘無束” 的地方 ${ }^{20}$ 。 她往湖心走去, 是她逃離家庭窒息感,追求新生活的最後的選擇。

\section{四、無處可逃}

《無聲告白》的主人公們竭力逃離扭曲的社會現實,但是, 奮力逃離並沒有使他們從身份焦慮中得以解 脫, 因為種族歧視如同堅硬的玻璃天花板, 使華裔後代永遠無法真正出逃, 獲得真正的自由和解放 ${ }^{20}$ 。尤其 是詹姆斯, 儘管他竭力模仿 “美國人”, 種族歧視的劣性使他始終被主流群體排擠在外。瑪麗琳吼出 “吅頭” 的一瞬間,宣告了詹姆斯“美國人”身份扮演的失敗。在爭吵中,瑪麗琳對詹姆斯怒吼: “我絕不會像你一樣 對員警吒頭!” “吒頭”是中國古代奴隸向權威俯首的形象, 瑪麗琳對詹姆斯吼出“吒頭”這個詞, 說明她認 為詹姆斯是個唯唯諾諾的中國人。而這種帶著西方優越感的評判, 恰恰是詹姆斯傾其一生想要擺脫的印記。 至於瑪麗琳, 為了打破偏見, 她不惜離家出走。但在返回家庭後, 她妥協了, 反省自己的行為是 “愚蚌的錯 誤”。更可悲的是,作為一個女權戰鬥者, 她竟然如同男權者,下意識地質疑女醫生的能力。瑪麗琳對女醫 生的不信任, 其實是女性對自我的懷疑, 反映了女性的邊緣化程度之高已深化到女性本體之内。這場對於性 別偏見的出逃,以女性對自我主體性的驅逐告終。

小說中內斯鄉往天空, 天空是自由的象徵,也是遙不可及的地方。内斯的逃離依賴天空, 暗示著他的逃 離是遙不可及的。同時, 莉迪亞的死是這個跨種族家庭的致命一擊。莉迪亞企圖跳進水裏解脫生活的壓力, 但死亡意味著結束, 莉迪亞結束了自己的生命, 也結束了改變生活的一切可能。另外, 因為莉迪亞是詹姆斯 和瑪麗琳逃離種族歧視和性別偏見的最後希望,莉迪亞的死也終結了他們擺脫困境的夢想。

\section{結語}

沿著對莉迪亞死亡線的追溯,伍綺詩在《無聲告白》中通過描繪主人公們的逃離,展現了社會邊緣人物 
對於種族尊重、性別平等和自由的渴望。本文深人剖析逃離本質後揭露了種族歧視和性別偏見是促使少數 族裔家庭無邊逃離的根源。詹姆斯一家不是個案, 而是少數族裔家庭在美國的代表。他們的悲劇遭遇反映 了種族歧視和性別偏見不僅給少數族裔的生活帶來影響, 甚至危及生命。詹姆斯一家抗爭的失敗, 證明逃離 現實只能暫時性撫慰創傷,並不能有效打破種族隔閡與性別偏見。

\section{注釋}

(1) Alexander, Chee. Sunday book review. The leftovers everything I never told you, by Celeste Ng. The New York Times Book Review, August 15, 2014.

(2)27蒲若茜:《華裔美國小說中的“唐人街”敘事》,《深圳大學學報》(人文社會科學版) 2006 年第 23 期, 頁 48-52。

(3) 許雙如: 《“他者”的面具政治——亞裔美國文學中的身份扮演與族裔主體性建構》,《當代外國文學》2011 年第 3 期, 頁 58-66。

(4) (6) (8)(9)(12)(17)(19202628 $\mathrm{Ng}$, Celeste. (2015). Everything I never told you. London: Penguin Books.

(5) 霍爾和諾德貝著, 溤川譯:《榮格心理學入門》,生活・讀書・新知三聯書店 1987 年版, 頁 48 。

(7)(24) Hall, Stuart. (2013). Representation: cultural representations and signifying practices. London: Sage Publications.

(10) 張劍: 《他者》,《外國文學》2011 年第 1 期, 頁 118-127。

(11) FU Channi. (2021). A study of Leslie Fielder's views of American novels in his cultural criticism. Asia-Pacific Journal of Humanities and Social Sciences, 1(3), 158-165.

(13) 弗朗茲・法曹著, 萬冰譯:《黑皮膚, 白颣具》, 譯林出版社 2005 年版, 頁 21 。

(14) Baldwin, Elaine et al. Introducing cultural studies. (2004). Beijing: Higher Education Press.

(15)De Beauvoir, Simone. The second sex. (2010). Constance Borde et Sheila Malovany-Chevallier. (Trans.). New York: Vintage Books.

(16) 約瑟芬・多諾萬著,趙育春譯:《女權主義的知識份子傅統》, 江蘇人民出版社 2003 版, 頁 178 。

(18) 凱特・米利特著,鐘良明譯:《性的政治》,社會科學文獻出版社 1999 年版, 頁 40 。

(21) Said, Edward W. (2003). Orientalism. England: Penguin Books Ltd.

(22) JIN Luobin. (2021). On translator's subjectivity as exemplified in the translation of Shengsi pilao by Goldblatt. Asia-Pacific Journal of Humanities and Social Sciences, 1(1), 50-60.

(23) Wong, Sau-ling C. Reading Asian American literature: from necessity to extravagance. (1993). New Jersey: Princeton University Press.

(25) Inge, W. R. (1940). Escape. Philosophy, 15(60): 386-399.

(Editor: Jasmine Liu) 